\title{
THE ROLE OF EXTENSION SUPPORT IN A COMMUNAL FARMERS' MARKET SYSTEM IN MHONDORO-MUBAIRA, ZIMBABWE
}

\author{
Muchesa, E. ${ }^{1}$, Nkosi, B.D. ${ }^{2}$; Zwane, E.M. ${ }^{3}$ and van Niekerk, J.A. ${ }^{4}$ \\ Correspondence author: E. Muchesa. Mail: evans@siyakhana.org
}

\section{ABSTRACT}

The objective of this research was to establish the role of agricultural extension in communal farmers' market systems by looking at possible ways in which it could intervene and support communal farmers in the marketing of produce. The study was conducted in the area of Mhondoro-Mubaira, which is situated in Mashonaland West Province in Zimbabwe. The target population comprised of 150 communal farmers and 25 extension officers. Poor technology and an under-resourced extension department is one of the factors identified by the extension officers $(84 \%)$ for poor extension delivery $(p=<0.464)$. The communal farmers referred to in this study have a negative perception of government-led extension support, especially in the area of agricultural market support. About half (56\%) of the farmers indicated that they do not receive any form of agricultural marketing extension support. The reasons for the poor ratings of government extension support by communal farmers include the following: they are hardly available (8.88\%); they are not knowledgeable enough (13.02\%); and they do not offer practical solutions (24.85\%). Communal food production and food security could be significantly improved if farmers receive appropriate input, training and extension support. Market linkage from the extension department could effectively boost income from agriculture enterprises and upgrade communal farmers who come from the most vulnerable section of the country's population.

Keywords: Agricultural Extension Excellence Model (AEEM), Agritex, Communal farming, Extension, Market systems

\section{INTRODUCTION}

The objective of this research was to establish and examine the functions and roles of agricultural extension in communal farmers' market systems. The study looked at possible ways in which extension could intervene and support farmers in marketing. According to Hoddinott and Skoufias (2003), agricultural extension (also known as agricultural advisory services) is crucial in promoting agricultural productivity, increasing food security, improving rural livelihoods, and promoting agriculture as an engine of pro-poor economic growth. According to Muchesa (2013), extension as a rural support service needs to meet the new challenges confronted in agriculture. These challenges include changes in the global food and agricultural system, agricultural marketing, food standards, growth in non-farm rural employment and agribusiness. This paper proposes the use of the Agricultural Excellence

\footnotetext{
${ }^{1} \mathrm{PhD}$ Student, University of the Free State, Email: evans@ siyakhana.org

${ }^{2}$ Senior Research and Lecturer, Agriculture Research Council of South Africa and University of the Free State, Email: dnkosi@arc.agric.za

${ }^{3}$ Senior Lecturer, University of Limpopo, Email: elliot.zwane@ul.ac.za

${ }^{4}$ Director, Centre for Sustainable Agriculture, Rural Development and Extension, University of the Free State, Email: vNiekerkJA@ufs.ac.za
} 
Extension Model (AEEM) as a comprehensive support model to improve extension services, including agricultural marketing extension (Düvel, 2007; Muchesa, 2013).

\section{CONCEPTUAL FRAMEWORK}

\subsection{Agricultural Extension Excellence Model (AEEM)}

According to Muchesa (2013), extension support to communal farmers is critical for agricultural development. The study uses the conceptual framework of the AEEM for programmed extension support. Agricultural extensionists and programme planners need theory to understand how to increase the likelihood that desired outcomes will be achieved. According to Düvel (2007), there is no one theory which is adequate to guide the creation, delivery and measurement of agricultural extension programmes. Therefore, the AEEM allows the selection of theories depending on the following: assessment of the situation; identification of the targeted population; understanding the behaviour to be addressed or changed; and the determination of outcomes that are strategic, measurable, achievable, relevant and timely.

The AEEM is a model which addresses the lack of information about the clientele, who are the farmers, by the creation of a database or by profiling farmers and corporations in terms of mainline, programmed extension activities. Thus, profiling a farmer will help to ascertain sustainable livelihoods (Worth, 2006).

The critical component of the AEEM is the use of the following social cognitive theory aspects:

- Self-efficacy, which is the "do-ability" factor and the measure of the ability to take the desired action.

- Do-ability, which is affected by perception of control. Control includes sufficient competence and confidence to act.

- Self-confidence, which is critical to taking action. Building confidence and a sense of control is based on where the consumer is at the start of the programme.

The AEEM is thus used in the monitoring and evaluation of extension programmes in terms of social cognitive theory. The following are the steps in the AEEM (Düvel, 2007; Muchesa, 2013):

1 - Data capturing information (creating a database), which includes facts about the farmer, hectares, production, personal information, and other sources of income contributing to the livelihood of the farmer.

2 - Group establishment or strengthening, which involves the extension worker establishing or strengthening the existing groups so as to increase the effectiveness of his extension activities, and employing "creative extension" or craft strategies suitable for the particular area. 2(i) - Creation or strengthening of linkages in the area, which entails the extension officer establishing collaboration so as to avoid duplication.

3 -Development or establishment of the basic stages of a programmed extension.

3(i) - The actual stages of implementation of a programmed extension activity, which includes for steps, namely consideration, investigation, preparation, and execution.

4 - Liaison and general which include the distribution of inputs, and the everyday reactive extension.

5 - Recommendation and report writing, updating and localising the extension approaches of relevance to the area. 
S. Afr. J. Agric. Ext.

Vol. 47 No. 2, 2019: 72 - 80

http://dx.doi.org/10.17159/2413-3221/2019/v47n2a504
Muchesa, Nkosi,

Zwane, van Niekerk

(License: CC BY 4.0)

\section{METHODOLOGY}

The target population for the research consisted of communal farmers ${ }^{5}$ and public extension officers located in the Mhondoro-Mubaira area, which is a constituency in the Chegutu District. A total of 150 communal farmers were interviewed through the use of cluster sampling. A total of 25 frontline extension personnel were interviewed using convenience sampling. Extension officers were selected on the basis that they work in the Ministry of Agriculture and serve the Mhondoro-Mubaira area. The primary data on extension support and agricultural marketing was collected by means of structured questionnaires. Semi-structured interviews were conducted with randomly selected farmers in the Mhondoro-Mubaira communal area. The questionnaires consisted of Likert-scale type questions, open-ended questions and multiplechoice questions. The data collected from the farmers was captured and coded in a Microsoft Excel spreadsheet and cleaned by checking for capturing errors. The Statistical Analysis System (SAS), Statistical 9.4 (2016) package was used to analyse the quantitative data. A Chisquare test was used to establish the associations within data. The researcher obtained the required permission from the respondents after informing them about the purpose of the interviews and the investigation. Thereafter, the respondents were assured that the information provided would remain confidential. The researcher confirmed that participation was voluntary, and that respondents had the right to withdraw at any time. Furthermore, the respondents were given the right to ask questions and obtain further clarity regarding the questions.

\section{RESULTS}

\subsection{Extension profile}

The majority of the extension officers $(80 \%)$ in the Mhondoro-Mubaira area were below the age of 40 . Furthermore, $32 \%$ of the female extension workers were below the age of 30 . Due to the government drive to increase the number of female extension workers and to recruit the youth in the department, the latest recruits are predominately young females $(\mathrm{p}=<0.157)$. Almost half of the extension workers $(48 \%)$ have at least a diploma qualification in agriculture. The high number of extension workers with a diploma qualification was due to the government drive to upgrade extensionists in Zimbabwe. The government negotiated with agricultural colleges and universities to offer block-release programmes to extension personnel (Dixie, 2005). There is a still a considerable number of extension workers with certificate qualifications in agriculture (36\%), although most of these are the new recruits, female extension workers and youths. Moreover, $68 \%$ of the extension workers have more than seven years' working experience. This is because, for the past five years, the government of Zimbabwe has not had the finance to recruit new staff, and only those in strategic positions approved by the Ministry of Finance are allowed to be recruited (Gálvez-Nogales, 2010).

\subsubsection{Availability of technology in the Department of Extension (Agritex)}

According to the results, $84 \%$ of the extension officers indicated that there is hardly any new technology available in the department of extension $(\mathrm{p}=<0.464)$. According to Commercial

\footnotetext{
${ }^{5}$ Communal farmers are farmers farming in designated areas according to the communal land act [Chapter 20:04]. Communal farmers constitute almost 50\% of the farmer category in Zimbabwe. Communal areas are generally poorly resourced and poorly supported (Claassens, 2008).
} 
Farmers Union of Zimbabwe (CFU, 2016) and Muchesa (2013), the department of extension recommends technologies that were mostly introduced 15 to 20 years ago.

\subsubsection{Farmer/ extension ratio}

The measure of intensity of extension coverage in an area or country is through the extension agent to farmer ratio (Food and Agriculture Organization (FAO), 2010). The recommended ratio of extension to farmer varies according to the nature of the farming operation (crops, livestock and mixed). In communal areas, the ratio is one extension worker to between 400 and 500 farmers (Hanyani-Mlambo, 2002). Most of the extension workers (44\%) serve between 151 and 200 farmers, which is way below the recommended ratio. This could have a positive effect on farmers only if the extension workers are equipped with updated technology. The extension to farmer ratio was found to be statistically significant $(\mathrm{p}=<0.507)$ as indicated by Table 1. The primary indicator used for measuring the intensity of extension coverage in a country is the extension agent to farmer ratio. The recommended ratio of extension to farmer varies according to the nature of the farming operation (crops, livestock and mixed). Moreover, the current extension to farmer ratio in Zimbabwe is commendable (FAO, 2010).

Table 1: Farmers served by extension $(\mathrm{N}=25)$

\begin{tabular}{|c|c|c|c|c|c|c|c|c|c|}
\hline \multirow{2}{*}{ Gender } & & \multicolumn{4}{|c|}{ Farmers served } & \multirow{2}{*}{ Total } & \multicolumn{3}{|c|}{ Chi-Square Test } \\
\hline & & \begin{tabular}{|l|}
$100-150$ \\
\end{tabular} & $151-200$ & $201-250$ & $>250$ & & $\overline{X^{2}}$ & df & p \\
\hline \multirow[t]{2}{*}{ Female } & Count & 3 & 6 & 2 & 4 & 15 & \multirow[t]{4}{*}{2.327} & \multirow[t]{4}{*}{2} & \multirow[t]{4}{*}{$<0.507$} \\
\hline & $\%$ of Total & $12 \%$ & $24 \%$ & $8 \%$ & $16 \%$ & $60 \%$ & & & \\
\hline \multirow{2}{*}{ Male } & Count & 0 & 5 & 2 & 3 & 10 & & & \\
\hline & $\%$ of Total & $0 \%$ & $20 \%$ & $8 \%$ & $12 \%$ & $40 \%$ & & & \\
\hline \multirow{2}{*}{ Total } & Count & 3 & 11 & 4 & 7 & 25 & & & \\
\hline & $\%$ of Total & $12 \%$ & $44 \%$ & $16 \%$ & $28 \%$ & $100 \%$ & & & \\
\hline
\end{tabular}

The majority of the extension workers $(76 \%)$ are in contact with the farmers at least once a month. The contact between farmers and extension workers is statistically significant $(\mathrm{p}=$ $<0.702$ ). The reasons given for extension workers not having more contact with farmers include no transport to visit the farmers and outdated technology to properly support the farmers.

The perceived level of knowledge of extension workers with regards to the mobilisation of farmers groups is relatively high as $76 \%$ of the extension workers perceive themselves as highly knowledgeable, rating themselves 5 on a 5 -point semantic scale $(\mathrm{p}=<0.702)$. The reasons given by the extension workers for the perceived level of group support include the following: I have been trained in group dynamics (36\%); I have been doing this for years (32\%); and I never trained but learnt on the job (32\%) $(\mathrm{p}=<0.005)$. According to Dixie (2005), for farmers to become more market-oriented, extension workers need to be in a position to advise them not only on how to grow crops, but also on how to market them. Extension workers also need to help farmers become better informed about the markets so as to enable them to make decisions which improve their marketing skills and access. Table 2 portrays the selfrating by the extension workers on their ability to help farmers market their produce (using a semantic scale of 1-5, 1 being the least and 5 the highest). Most of the extension workers (76\% with a rating of 5) perceive themselves as highly competent in helping farmers market their 
produce. The ratings are also statistically significant $(\mathrm{p}=<0.702)$. Despite the very high rating by the extension workers in their ability to help farmers market their produce, $41.89 \%$ (rated below 3 ) of the communal farmers were not satisfied with the support.

Table 2: Ratings of ability to help farmers market produce by extension ( $N=25)$

\begin{tabular}{|c|c|c|c|c|c|c|c|}
\hline \multirow{2}{*}{ Gender } & & \multicolumn{2}{|c|}{$\begin{array}{l}\text { Rating of ability to help } \\
\text { farmers market produce }\end{array}$} & \multirow{2}{*}{ Total } & \multicolumn{3}{|c|}{ Chi-Square Test } \\
\hline & & 4 & 5 & & $\mathrm{X}^{2}$ & df & $\mathbf{p}$ \\
\hline \multirow{2}{*}{ Female } & Count & 4 & 11 & 15 & \multirow[t]{4}{*}{0.146} & \multirow[t]{4}{*}{1} & \multirow[t]{4}{*}{$<0.702$} \\
\hline & $\%$ of Total & $16 \%$ & $44 \%$ & $60 \%$ & & & \\
\hline \multirow{2}{*}{ Male } & Count & 2 & 8 & 10 & & & \\
\hline & $\%$ of Total & $8 \%$ & $32 \%$ & $40 \%$ & & & \\
\hline \multirow{2}{*}{ Total } & Count & 6 & 19 & 25 & & & \\
\hline & $\%$ of Total & $24 \%$ & $76 \%$ & $100 \%$ & & & \\
\hline
\end{tabular}

The constraints preventing farmers from marketing their produce, as perceived by the extension workers, are listed according to priority as follows: high transport costs as an impediment to farmers (36\%); no knowledge of marketing (21\%); poor road infrastructure (18\%); poor market infrastructure $(14 \%)$; and poor prices for the produce $(11 \%)$. The list of constraints provided by the extension workers is statistically significant $(\mathrm{p}=<0.702)$.

\subsection{Communal farmers' profile}

According to the results, women are the largest communal landholders $(68 \% ; \mathrm{p}=0.0001)$. The typical land holding per communal household is between $4-5$ ha $(66 \%$; $=0001)$, and this includes the homestead. Furthermore, $18.7 \%$ of the communal farmers are above 60 years, $40 \%$ are in the 51-60 years age group, while $68.7 \%$ are above the age of 50. This is a common age distribution in the communal areas of Zimbabwe. This is because most individuals relocate permanently to the communal areas when they retire. Female farmers make up more than $60 \%$ of the farmers in communal areas in the Mhondoro-Mubaira area, as migration to town or other countries for males is still a dominate phenomenon (Evenson, 2000). With regards to the educational level for the communal farmers in the Mhondoro-Mubaira communal area, the results show that $73 \%(\mathrm{p}=0.0001)$ of the farmers have only secondary level education and below. Consideration of educational level of the farmers is important for agricultural extension delivery methods (Groenewald, 2003).

Table 3 indicates the rating of sources of agricultural inputs and their availability to the farmers. A considerable number of farmers $(54.67 \%$ with a 3 rating) indicated that their major source of agricultural input is through household purchases. The rating is statistically significant $(\mathrm{p}=$ 0.0072). The major significant source of agricultural input for the farmers comes in the form of gifts and remittances from relatives $(71.33 \%)$, which most rural farmers depend on for their farms $(\mathrm{p}=0.0010)$. Government programmes supplying inputs were rated low, as some of the farmers perceive that these programmes are mired by corruption, and they are not a reliable source of agricultural inputs. 
S. Afr. J. Agric. Ext.

Vol. 47 No. 2, 2019: 72 - 80

http://dx.doi.org/10.17159/2413-3221/2019/v47n2a504
Muchesa, Nkosi,

Zwane, van Niekerk

(License: CC BY 4.0)

Table 3: Ratings of source of agricultural inputs and availability $(\mathrm{N}=150)$

\begin{tabular}{|c|c|c|c|c|c|c|c|c|c|c|c|}
\hline \multirow{3}{*}{ Market type } & \multicolumn{8}{|c|}{ Ratings } & \multicolumn{3}{|c|}{ Chi-Square Test } \\
\hline & \multicolumn{2}{|l|}{1} & \multicolumn{2}{|l|}{2} & \multicolumn{2}{|l|}{3} & \multicolumn{2}{|l|}{4} & \multirow{2}{*}{$X^{2}$} & \multirow{2}{*}{ df } & \multirow[b]{2}{*}{$\mathbf{p}$} \\
\hline & $\mathbf{F}$ & $\%$ & $\mathbf{F}$ & $\%$ & $\mathbf{F}$ & $\%$ & $\mathbf{F}$ & $\%$ & & & \\
\hline Household purchases & 0 & 0 & 68 & 45.33 & 43 & 28.67 & 39 & 26 & 9.8800 & 2 & 0.0072 \\
\hline GVT programmes & 20 & 13.33 & 90 & 60 & 40 & 26.67 & 0 & 0 & 52.0000 & 2 & $<.0001$ \\
\hline NGOs & 89 & 59.33 & 32 & 21.33 & 29 & 19.33 & 0 & 0 & 45.7200 & 2 & $<.0001$ \\
\hline Gifts/ Remittances & 0 & 0 & 43 & 28.67 & 71 & 47.33 & 36 & 24 & 13.7200 & 2 & 0.0010 \\
\hline
\end{tabular}

Table 4 portrays the major sources of agricultural extension services for the farmers and their level of satisfaction using a 5-point semantic scale. The majority of the communal farmers $(80 \%)$ were not satisfied with the government extension services $(p=<.0001)$. However, $87.73 \%$ indicated that they were satisfied with the extension support given by the NGOs, another major source of agricultural extension service for the farmers, and this was found to be statistically significant $(\mathrm{p}=<.0001)$. The communal farmers also use private extension services in the form of contract farming, major agribusiness firms and contract farmers, who provide agronomic advice to the farmers. Almost all of the farmers $(87 \%)$ indicated they were satisfied with the extension support provided $(\mathrm{p}=<.0001)$.

The reasons for the poor ratings for government extension support by the communal farmers questioned in the study include the following: they are hardly available (8.88\%); they are not knowledgeable enough (13.02\%); and they do not offer practical solutions $(24.85 \%)$. In addition, some of the reasons for favourable ratings for private and NGO extension are as follows: they are very knowledgeable $(16.57 \%)$; they are always available when needed $(27.22 \%)$; and they offer practical solutions $(9.47 \%)(\mathrm{p}=<.0001)$. The reasons given by the farmers directly correspond to the under-capacitated, poorly resourced public extension services and relatively efficient private extension services which are commodity orientated (Hanyani-Mlambo, 2002). 
S. Afr. J. Agric. Ext.

Vol. 47 No. 2, 2019: 72 - 80

http://dx.doi.org/10.17159/2413-3221/2019/v47n2a504
Muchesa, Nkosi,

Zwane, van Niekerk

(License: CC BY 4.0)

Table 4: Major source of agricultural extension services and level of satisfaction $(\mathrm{N}=150)$

\begin{tabular}{|c|c|c|c|c|c|c|c|c|c|c|c|}
\hline \multirow{3}{*}{ Extension } & \multicolumn{8}{|c|}{ Ratings } & \multirow{2}{*}{\multicolumn{3}{|c|}{ Chi-Square Test }} \\
\hline & \multicolumn{2}{|c|}{1} & \multicolumn{2}{|l|}{2} & \multicolumn{2}{|l|}{3} & \multicolumn{2}{|l|}{4} & & & \\
\hline & $\mathbf{F}$ & $\%$ & $\mathbf{F}$ & $\%$ & $\mathbf{F}$ & $\%$ & $\mathbf{F}$ & $\%$ & $\mathrm{X} 2$ & df & $\mathbf{p}$ \\
\hline $\begin{array}{l}\text { Government extension } \\
\text { services }\end{array}$ & 15 & 10 & 105 & 70 & 30 & 20 & 0 & 0 & 93.0000 & 2 & $<.0001$ \\
\hline Private organisation & 0 & 0 & 13 & 12.3 & 69 & 65.1 & 24 & 22.6 & 49.8302 & 2 & $<.0001$ \\
\hline $\begin{array}{l}\text { Non-governmental } \\
\text { organisation (NGO) }\end{array}$ & 0 & 0 & 13 & 13 & 39 & 39 & 48 & 48 & 19.8200 & 2 & $<.0001$ \\
\hline
\end{tabular}

Figure 1 displays the number of communal farmers receiving agricultural marketing extension services. Less than half of the farmers $(44 \%)$ reported that they receive agricultural marketing services from either public extension or private extension. A large number of the communal farmers $(56.0 \%)$ do not receive any form of agricultural marketing extension support. Agricultural marketing extension support involves any information from the extension officers about agricultural markets, and these include input and output markets (Muchesa, 2013).

The number of farmers receiving agricultural marketing information is statistically significant $(\mathrm{p}=0.1416)$. According to Kitetu (2005), production and food security can be significantly improved in the communal areas in Zimbabwe if farmers receive appropriate input, training and extension support. Furthermore, market linkage by communal farmers can effectively boost income from agriculture enterprises and upgrade communal farmers who come from the most vulnerable section of the rural population.

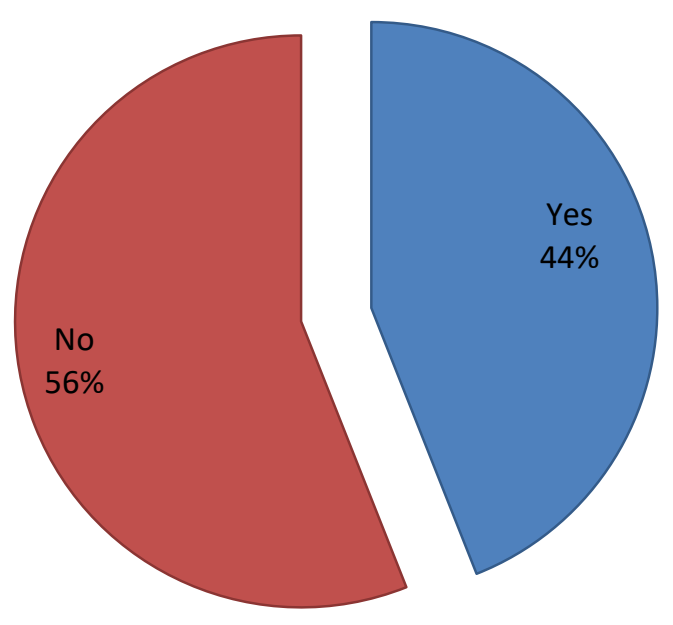

Figure 1: Communal farmers receiving agricultural marketing extension services $(\mathrm{N}=150)$ 
S. Afr. J. Agric. Ext.

Vol. 47 No. 2, 2019: 72 - 80

http://dx.doi.org/10.17159/2413-3221/2019/v47n2a504
Muchesa, Nkosi,

Zwane, van Niekerk

(License: CC BY 4.0)

Table 5 shows the ratings of communal farmers who are receiving agricultural marketing extension for the level of assistance in agricultural marketing by government extension personnel. Less than half of the farmers $(41.89 \%)$ rated this aspect below 3 on a 5-point semantic scale. This means nearly half of the farmers are not satisfied by the agricultural marketing support given by the government extension officers. The rating given by the farmers is statistically significant $(\mathrm{p}=0.0866)$.

Table 5: Ratings of the level of assistance in agriculture marketing by extension personnel $(\mathrm{N}=150)$

\begin{tabular}{|c|c|c|c|c|c|c|c|c|c|c|c|}
\hline \multirow{3}{*}{$\begin{array}{l}\text { Agriculture marketing } \\
\text { extension }\end{array}$} & \multicolumn{8}{|c|}{ Rating } & \multirow{2}{*}{\multicolumn{3}{|c|}{ Chi-Square Test }} \\
\hline & \multicolumn{2}{|c|}{1} & \multicolumn{2}{|l|}{2} & \multicolumn{2}{|l|}{3} & \multicolumn{2}{|l|}{4} & & & \\
\hline & $\mathbf{F}$ & $\%$ & $\mathbf{F}$ & $\%$ & $\mathbf{F}$ & $\%$ & $\mathbf{F}$ & $\%$ & $\mathrm{X}^{2}$ & df & $\mathbf{p}$ \\
\hline Marketing extension & 0 & 0 & 31 & 41.89 & 27 & 36.49 & 16 & 21.62 & 4.8919 , & 2 & 0.0866 \\
\hline
\end{tabular}

\section{CONCLUSION}

The department of extension, which was examined in the study, has a relatively young generation of extension officers with $80 \%$ of the extension workers being below the age of 40 , and $60 \%$ being female. This is of direct benefit to farmers because more than $60 \%$ of the landholders in the communal areas are female farmers. Poor technology and an underresourced extension department are factors identified by the extension officers (84\%) for poor extension delivery $(\mathrm{p}=<0.464)$. Moreover, extension worker and farmer contact is low with $76 \%$ of the extension workers indicating that they, at most, have contact with farmers once a month. According to the results, communal farmers have a poor perception of government-led extension support, especially in the area of agricultural market support. Furthermore, $56 \%$ of the farmers indicated that they do not receive any form of agricultural marketing extension support. There are several reasons for the poor rating of government extension support by the communal farmers of the study, namely that they are hardly available $(8.88 \%)$, they are not knowledgeable enough (13.02\%), and they do not offer practical solutions (24.85\%).

The communal farmers featured in the study, amongst other factors which include poor extension support, also feel that poor roads, infrastructure, and poor prices are major constraints for marketing their produce. Communal food production and food security could be significantly improved in the communal areas of Zimbabwe if farmers receive appropriate input, training and extension support.

Extension support is critical in improving the communal agricultural market system in Zimbabwe, despite it being poorly rated by communal farmers. The conceptual framework of the AEEM can be a useful tool in offering programmed extension support and creating market linkages for farmers. Market linkage from extension departments could effectively improve income from agricultural enterprises and upgrade communal farmers who come from the most vulnerable section of the country's population.

\section{REFERENCES}

CLAASSENS, A., 2008. Land, power \& custom: Controversies generated by South Africa's communal land rights act. Cape Town: Juta and Company Ltd. 
COMMERCIAL FARMERS UNION OF ZIMBABWE (CFU), 2016. Commercial Farmers' Union of Zimbabwe Annual Congress 2016. Available from: http://www.cfuzim.org/ cfuzimb/images/brochure2016.pdf

DIXIE, G., 2005. Horticultural Marketing, marketing extension guide 5. Rome: Food and Agriculture Organization of the United Nations.

DÜVEL, G.H., 2007. Monitoring in extension: From principles to practical implementation. $S$. Afr. J. Agric. Ext., 36(1):78-93.

EVENSON, R.E., 2000. Economic impacts of agricultural research and extension. Yale University: Elsevier Science.

FOOD AND AGRICULTURE ORGANIZATION (FAO), 2010. Facing the challenges of climate change and food security: The role of research, extension and communication for development. Rome, Italy.

GÁLVEZ-NOGALES, E., 2010. Agro-based cluster in developing countries: Staying competitive in a globalised economy. Agricultural Management, Marketing and Finance Occasional Paper. FAO. Rome, Italy.

GROENEWALD, J.A., 2003. Conditions for successful land reform in Africa. Paper presented to Pre-IAAE-Conference on African Agricultural Economics. Bloemfontein, South Africa.

HANYANI-MLAMBO, B.T., 2002. Strengthening the pluralistic agricultural extension system: A Zimbabwe case study. Available from: www.fao.org/DOCREP/005/AC913E/ac913e00.htm

HODDINOTT, J. \& SKOUFIAS, E., 2003. The impact of PROGRESA on food consumption. IFPRI Discussion Paper No. 150. The United Nations University, Japan.

KITETU, C.W., 2005. Farmer groups as a way of mobilising citizen participation in development: An example from Kenya. Paper presented to the 11th General Assembly. Maputo, Mozambique.

MUCHESA, E., 2013. Sustainable extension support to land reform beneficiaries in Zimbabwe (Mashonaland West). MSc Thesis, University of Pretoria.

WORTH, S.H., 2006. Agriflection: A learning model for agricultural extension in South Africa. J. Agric. Educ. Ext., 12(3):179-193. 
